\title{
68, 50 anos depois: memórias de frei Oswaldo Rezende sobre a resistência da esquerda católica à ditadura militar
}

\author{
Miriam Hermeto* \\ ORCID iD 0000-0003-1067-1425 \\ Univer sidade Federal de Minas Gerais, Faculdade de Filosofia e Ciências Humanas, Belo Horizonte, Brasil
}

\section{Gabriel Amato*}

ORCID iD 0000-0003-0655-4285

Instituto Federal do Sul de Minas Gerais, Câmpus Avançado Três Corações, Três Corações, Brasil

\section{Nelyane Santos}

ORCID iD 0000-0002-2876-6126

Universidade Federal de Minas Gerais, Faculdade de Filosofia e Ciências Humanas, Belo Horizonte, Brasil

Resumo: Este texto compóe-se de uma apresentação de entrevista pública realizada com frei Oswaldo Rezende pelo Núcleo de História Oral do Laboratório de História do Tempo Presente da UFMG (NHO/ LHTP), em 13 de dezembro de 2018, seguida de uma transcrição editada. Frei Oswaldo ordenou-se frade

Doutora em História, mestre em Educação, licenciada e bacharel em História pela Universidade Federal de Minas Gerais (UFMG). Professora do Departamento de História e do Programa de Pós-Graduação em História da UFMG e pesquisadora do Núcleo de História Oral do Laboratório de História do Tempo Presente da UFMG. E-mail: miriamhermeto@gmail.com.

Doutorando, mestre e licenciado em História pela Universidade Federal de Minas Gerais (UFMG). Professor EBTT no Instituto Federal do Sul de Minas Gerais (IFSULDEMINAS), Câmpus Avançado Três Corações, e pesquisador do Núcleo de História Oral do Laboratório de História do Tempo Presente da UFMG. E-mail: amatolgabriel@gmail.com.

* Doutora e mestre em Artes, bacharel em Restauração e Conservação de Bens Culturais Móveis e licenciada em História pela Universidade Federal de Minas Gerais (UFMG). Pesquisadora do Núcleo de História Oral do Laboratório de História do Tempo Presente da UFMG. E-mail: nelyanehistart@ gmail.com. 
dominicano na década de 1960, quando também estudou Filosofia na Universidade de São Paulo (USP) e atuou em atividades de planejamento da Açấo Libertadora Nacional (ALN), organização de luta armada. No dia do cinquentenário do AI-5, em contexto de retorno da extrema-direita ao poder e diante de uma plateia universitária, Oswaldo narrou suas lembranças do entorno de 1968, assumindo a tarefa com um senso de "dever" de memória para com as geraçóes mais jovens.

Palavras-chave: Dominicanos. 1968. Luta armada. Dever de memória.

\title{
68, 50 Years Later: friar Oswald Rezende's memoirs about the catholic left's resistance to the military dictatorship
}

\begin{abstract}
This text consists of a presentation of a public interview conducted with friar Oswaldo Rezende by the "Núcleo de História Oral do Laboratório de História do Tempo Presente (NHO/LHTP)", on december 13th, 2018, followed by its edited transcript. Frei Oswaldo became a dominican friar in the 1960s, when he also studied Philosophy at "Universidade de São Paulo (USP)" and worked in planning activities for the "Ação Libertadora Nacional (ALN)", an armed struggle organization. On the day of the 50th anniversary of the AI-5, in the context of the return of the far right to power and in the presence of a student audience, Oswaldo narrated his memoirs about the surroundings of 1968, assuming this task with a sense of "duty" of memory towards the younger generations.
\end{abstract}

Keywords: Dominicans. 1968. Armed struggle. Duty of memory.

Terça-feira, 13 de dezembro de 2018. A noite que havíamos escolhido para entrevistar Oswaldo Augusto de Rezende Júnior, frei dominicano de 74 anos, era carregada de sentidos de memória, em escalas individuais e sociais. A data marcava os 50 anos do Ato Institucional $n^{0} 5$ (AI-5) - uma das medidas de aprofundamento da repressáo no contexto da ditadura militar brasileira. O AI-5 teve impactos não apenas na trajetória de vida de frei Oswaldo, mas também no destino de sua geração e da sociedade brasileira, de forma mais ampla. Em 2018, pouco tempo depois da eleiçáo de um candidato da extrema-direita à presidência da República a partir de uma plataforma política que incluía uma memória positiva (quando não negacionista) da ditadura que editara o AI-5, convidávamos o frei para se lembrar daqueles tempos em uma entrevista pública (Santhiago, 2018). Nossa expectativa era a de que, diante de uma nova presença do autoritarismo, o frei lançasse novos olhares sobre sua trajetória, auxiliando-nos a lançar olhares também novos para a história do tempo presente.

Antes de participar da entrevista, frei Oswaldo era conhecido de grande parte de nós, seja por meio do estudo do contexto da ditadura militar ou a partir de notícias sobre a sua atuação posterior à ditadura, como prior da Ordem Dominicana no Convento Nossa Senhora Aparecida, em Belo Horizonte. O contato inicial com o frei foi feito por Nelyane Santos. Ele prontamente aceitou o convite, qualificando o seu aceite como um "dever". Para conduzir o diálogo com o frei, convidamos o professor 
Rodrigo Patto Sá Motta, reconhecido especialista no campo da historiografia sobre a ditadura militar e coordenador do Laboratório de História do Tempo Presente (LHTP), onde está abrigado o núcleo de pesquisa que realizou a atividade. A entrevista, que contou também com questóes do público, durou cerca de duas horas e foi estruturada a partir de um roteiro elaborado pela equipe de pesquisadores do Núcleo de História Oral (NHO) do LHTP após pesquisa bibliográfica sobre as relações entre religião e política no Brasil dos anos 1960.

Internamente, o NHO/LHTP vivia uma conjuntura particular, que nos levou à decisão de realizar esta entrevista. Encerrávamos a fase de coleta de dados de um projeto de pesquisa sobre o cinquentenário do ano de 1968, no qual foram realizadas entrevistas públicas com sujeitos de diferentes atuaçóes em Belo Horizonte e regiáo metropolitana. Produzimos um conjunto de oito entrevistas, com sujeitos que exerciam papéis sociais distintos cinquenta anos antes, na medida em que nosso próprio contexto político tornava-se, mês a mês, um dado fundamental para a produção de novas narrativas sobre o passado ditatorial. ${ }^{1}$ Em dezembro de 2018, concluímos que nossas atividades naquele ano deveriam ser finalizadas com um evento de "descomemoração" do AI-5, oportunidade em que nos colocaríamos a ouvir e aprender com as experiências de frei Oswaldo. Assim como fizemos com as entrevistas anteriores, discutimos coletivamente o roteiro de entrevista, num processo de pesquisa sobre a ditadura militar e de formação continuada da equipe.

As memórias narradas por frei Oswaldo trazem dados interessantes tanto do ponto de vista das relaçóes entre Igreja, Estado e movimentos de resistência (armada ou não) à ditadura militar, como dos sentidos que ele atribui ao passado em seu exercício de lembrança, fatores que justificam a publicação desta versão editada da entrevista. Em parte, essa relevância é explicada pela própria história de vida do entrevistado. Oswaldo nasceu em 15 de novembro de 1944, em Pompeia, interior de São Paulo. Na década de 1960, ainda jovem, participou dos movimentos da Ação Católica e se aproximou das pautas de justiça social do catolicismo progressista, no contexto da recepção das ideias contidas em duas encíclicas do Papa João XXIII: Mater et Magistra (1961) e Pacem in Terris (1963). Nesses movimentos, Oswaldo encontrou sua vocaçáo religiosa e decidiu se integrar à Ordem dos Dominicanos. Após ordenar-se frade em Belo Horizonte, em 1965, foi transferido para o Convento de Perdizes, em Sáo Paulo, no ano de 1967. Na nova cidade, recebeu autorização para estudar Filosofia na Universidade de São Paulo

Além dos autores deste texto, também participaram do projeto os pesquisadores Carolina Dellamore Batista Scarpelli, Paula Elise Ferreira Soares, Gabriela Fischer Fernandes Corradi, Marina Mesquita Camisasca, Carolina Silva Horta Machado, Samuel Antunes de Sousa, Bruna Piteres Porto e Mariana Loures Morais, a quem agradecemos pela parceria ao longo do trabalho e pelos aprendizados coletivos. Agradecemos, em especial, ao professor Rodrigo Patto Sá Motta, coordenador do LHTP, por ter aceitado nosso convite para conduzir esta entrevista com frei Oswaldo Rezende, e ao Samuel Antunes de Sousa, que preparou a transcrição literal do áudio. 
(USP), estreitou contatos com o movimento estudantil e passou a agir na proteçáo de militantes da esquerda armada, juntamente com outros freis dominicanos.

Em sua colaboração com um dos mais importantes grupos de guerrilha urbana, a Ação Libertadora Nacional (ALN), esteve em contato com Carlos Marighella e com outras lideranças políticas de destaque. Contemporâneo de Frei Tito e Frei Betto na formação religiosa, frei Oswaldo também relata com intimidade essas (e outras) relaçóes de amizade e companheirismo com confrades que conduziu para a organização. Nesse sentido, a entrevista dialoga com outro documento de memória - o livro Batismo de sangue: os dominicanos e a morte de Carlos Marighella, publicado por Frei Betto em 1982. Nele, seu autor esclarece que, com frei Oswaldo, tinha em comum "a militância na JEC [Juventude Estudantil Católica] (através da qual se despertou nossa vocação religiosa), o interesse pela Teologia e a impossibilidade de separar a fé cristá do compromisso social" (Betto, 1982, p. 45).

Do ponto de vista dos sentidos atribuídos ao seu passado a partir do presente de 2018, a entrevista que aqui apresentamos também possibilita importantes reflexóes sobre novas gestôes de experiências sensíveis, demandadas a cada novo tempo presente. Como aponta ele mesmo no início e no final de sua entrevista, é a partir da lógica do dever da memória que frei Oswaldo narra as suas experiências. Aqui, duas variáveis tornam sua prática de lembrança ainda mais interessante. Primeiro, o papel da lógica dos grupos de idade e das geraçóes. Frei Oswaldo falou, na velhice, sobre a experiência da juventude. Nesse sentido, ele narra os sentidos de, em sua juventude vivida em meio à ditadura, ter experimentado a estupefação e a esperança para lidar com o arbítrio. Mas narra também o sentimento de, na velhice, lidar com a surpresa do possível retorno do arbítrio, após a eleição de 2018. Segundo, ele realizou este exercício de memória diante de pesquisadores da área de História e de um público, que percebeu como bem mais jovens que ele. É também nesse sentido que a sua entrevista ganhava tons de dever de memória. Na continuidade da história, cabe, em sua visão, ensinar o vivido para aqueles que viveráo por mais tempo.

\section{Entrevista}

Oswaldo Rezende - Boa noite a todas e a todos. Um prazer estar aqui e... Não que o assunto seja o meu assunto preferencial, mas por um sentimento de dever. Eu testemunhei alguma coisa, eu a vivi e é uma coisa que não pode mais se repetir. É neste sentido que eu considero um dever cada vez que me chamam para testemunhar sobre estes tristes acontecimentos que se passaram no nosso país. [...].

Rodrigo Patto Sá Motta - Sobre as pessoas com quem se envolveu em sua formação religiosa na juventude, o Sr. considera que tinham uma visão próxima à sua para os 
temas políticos e sociais?

OR - Sim, sem dúvida. Naquela época se falava de uma maneira muito clara da necessidade - inclusive o clero - da Revoluçãao Brasileira. O sentido da revolução não eram armas, tiros na rua. A revolução no sentido próprio que Marx dá a essa palavra: uma transformação rápida e profunda no sistema social vigente. Ajuntando um terceiro caráter irrevogável, não há volta para trás. Nesse sentido, já digo para vocês que para mim só houve duas revoluçóes no mundo, a Inglesa e a Francesa. Não houve volta para trás. O feudalismo não voltou depois da Revolução Francesa. Mas o capitalismo voltou - e a galope - depois da Revolução de 1917, na Rússia. Então, é preciso situar bem, não é? Quando se falava de revolução, era essa transformação. E o clero era, em boa parte, favorável. É uma honra para mim saber que quase todos os padres com que eu tive contato tornaram-se bispos. Eram simples padres, escolhidos a dedo, depois, primeiro pelo grande bispo que teve em Ribeiráo Preto, Dom Luís do Amaral Mousinho - infelizmente desconhecido, um grande reformador. Morreu jovem, 49 anos, mas deixou um grupo de padres, quase todos se tornaram bispos. Isso graças ao Papa Paulo VI, para quem os militares brasileiros eram gângsteres. E aí houve o meu encontro com os dominicanos, frei Carlos Josaphat. Quando o Papa João XXIII lança a encíclica Mater et Magistra, que é talvez um dos documentos mais revolucionários do século XX, sobre a justiça social, há um abalo, porque ele fala até de socialização, como um fenômeno natural e inevitável da sociedade. Frei Carlos Josaphat deu um curso sobre essa encíclica, que merece ser conhecida - muito do que está lá ainda é programa. Por esse curso, [realizado] na nossa igreja atual de Perdizes, o mundo político inteiro passou. Desde Miguel Arraes, que estava de passagem em São Paulo. Ele ia, era todas as quartas-feiras. E aí, das discussóes que nasceram deste curso saiu uma coisa muito importante: a necessidade de uma imprensa livre no Brasil, a necessidade de uma imprensa desvinculada do mundo econômico. Daí criou-se um grupo que criou o jornal Brasil Urgente, o único que não teve nenhuma publicidade e que anunciou, em seu último número, na primeira página: “O golpe de Estado está pronto”.

RM - Nessa época o Sr. já estava no Seminário?

OR - Não. Para entrar, eu hesitei entre Dominicanos - que eu conheci através do frei Carlos, que era muito claro - e os Jesuítas, por causa de um deles, infelizmente falecido, que tem muito a ver com essa universidade, que é o padre Vaz, Henrique de Lima Vaz. Então, [...] eu tive que escolher. O Dom Luís falou: "Você está em dúvida, tem um seminário que se chama seminário vestibular e você fica pensando nisso". E eu passei um ano ali, até que eu procurei definitivamente os Dominicanos. Em 1965, eu entrei no noviciado, aqui em Belo Horizonte, o Convento da Serra. Do nosso noviciado, sobramos dois: o Frei Betto e eu. Somos do mesmo ano. Só as nossas vocações se 
separaram, no ano em que ele foi para a cadeia, eu fui para o exílio [risadas do público]. Talvez poderia ter sido diferente, náo é? Fazer o quê? Eu estava no noviciado, e eu conto isso para vocês verem uma das razōes pelas quais eu entrei na ordem. Já havia um golpe de Estado. Estávamos o Betto, eu e os outros noviços, nós usávamos o hábito dominicano dentro do convento. E no fim da tarde o calor estava muito forte, durante o momento de meditaçấo que nós tínhamos dentro do programa - pedimos para não fazer na capela, mas no jardim do convento. E daí a pouco chegou a polícia. Nós ali, rezando, a polícia federal invadiu. Porque estava de passagem, em Belo Horizonte, o marechal Castello Branco, presidente da República. O primeiro ditador que vinha em visita ao seu querido amigo, Magalháes Pinto. E a residência do governador era, e como deve ser até hoje, atrás do convento. A cidade terminava ali na Rua do Ouro com a Rua dos Dominicanos. E construíram o Palácio das Mangabeiras. Inevitavelmente, o marechal teria que passar a lado do convento e, evidentemente, a polícia, que tem a obrigação de defender um presidente da República, sobretudo quando ele é marechal e ditador, resolveu dar um pulo no convento para ver se náo havia o perigo de alguém dar um tiro no Castello Branco. Isso nos ofendeu profundamente. Nós, frades dominicanos, geralmente, usamos uma túnica, o escapulário branco, mas, sobre tudo isso, vem uma capa preta. Todas as janelas do noviciado, onde nós estávamos, as nossas celas, davam para a rua onde ia passar o marechal Castello Branco. Nós colocamos as nossas capas pretas na janela. De tal maneira que, quando o marechal passou, ele deve ter olhado: "O que é isso?"; e o governador, evidente: "São os dominicanos, excelência!” [risadas do público]. E nós marcamos assim, um grupo de jovens, a nossa oposição ao marechal. Aliás, "marechal" não sei por quê. Na França, na Alemanha, em qualquer país, o marechal é um general que esteve no comando de um exército contra um outro exército inimigo. Não estou falando de uma companhia, de um batalhão, de um regimento, [mas] de um exército todo. E venceu. Aí ele passa a ser marechal. No Brasil, nós temos marechais que só ameaçaram o próprio povo que deviam defender. Marechal, não é? Nós estamos nos perdendo, nós já estamos começando a falar mal do marechal [risadas do público].

RM - Bom, se o Sr. falasse bem é que iríamos nos espantar [risadas do público]. O Sr. teve contato com a USP, com o curso de Filosofia, na mesma época?

OR - Sim. Assim que terminou o noviciado, fizemos nossos votos, primeiro por três anos, aí fomos para Sáo Paulo no convento de Perdizes, isso em 1966, onde eu ia fazer Filosofia. O convento de Perdizes era, propriamente falando, um centro de esquerda contra a ditadura. Ali passava todo mundo. $\mathrm{Na}$ missa das $11 \mathrm{~h}$, por exemplo, em que geralmente era o prior que pregava, ficava gente de fora [da igreja] e vinha gente de Sáo Paulo inteiro. Eu temo que um terço devia ser comunista ou simpatizante de comunismo, porque era um dos lugares em que, dizia-se, se podia falar e discutir contra 
a ditadura no Brasil. Então, eu fiz o ano de Filosofia. Eu estava tão interessado em Filosofia que propus ao provincial, que é o nosso superior no Brasil, de fazer os estudos na USP. Para entrar em contato com os estudantes. Eu queria só estudar Filosofia, então ele falou: "Vou pensar". No fim desta visita canônica - visita canônica é uma visita de inspeção - ele anunciou a todo mundo: "Eu aceitei o pedido de frei Oswaldo para que ele estude Filosofia na USP". Teve gente que foi contra: "Você está mandando um. No ano que vem tem uma fila que vai, vão todos para lá”. O fato é que eu fui e fiz questão de estudar para o vestibular. Havia cursinhos. Os meus superiores, professores, diziam: "Você não precisa, você já fez Filosofia". Eu: "Sim, mas eu quero conhecer". E lá que eu fui encontrar algumas e alguns dos meus mais preciosos amigos e companheiros de luta. Eram estudantes que davam aula para aqueles que iam prestar. Prestei o meu vestibular como todo mundo e, aliás, eu tive uma sorte incrível. Porque quem me examinou foi o professor Bento Prado. E ele, se ocupando de outra coisa, me falou: "Me dê uma definição de verdade". E eu disse "Veritas est adaequatio mens ad rem", Tomás de Aquino. Ele acordou. "Onde é que você aprendeu?" Claro, para o Bento era uma coisa estranhíssima. "Eu sou dominicano, eu sou frade dominicano". "Ah, vai embora meu filho, a gente se encontra ano que vem" [risadas do público]. Pronto, eu sabia que eu tinha passado, não é? O fato é que eu comecei, não é? Um frade dominicano, ordem conhecida pelas suas posiçóes. Para vocês verem até que ponto: o Darcy Ribeiro resolveu fazer a Universidade de Brasília [UnB], pelo sonho, que devia ser o centro intelectual de reformas na América Latina, para onde ele levaria o que existia de melhor no Brasil. E ele é chamado para ser chefe da Casa Civil da presidência da República, do João Goulart. Ele tem que deixar alguém no lugar dele, quem é que ele chama? O provincial dos dominicanos, frei Mateus Rocha.

$\mathbf{R M}$ - Que ele convidou para dirigir o Instituto de Teologia da UnB, não é isso?

OR - Além disso, fez questão que houvesse dentro do campus uma faculdade de Teologia dos dominicanos, um convento lindíssimo. Oscar Niemeyer dizia: "Eu já fiz um palácio, já fiz uma catedral, está me faltando um convento, eu faço o convento de vocês". Quando eu vi a planta, ia ser maravilhoso, o claustro do convento era em cima, o jardim suspenso da Babilônia [risadas do público]. É claro que isso tudo terminou rápido com o golpe de Estado, o marechal Castello Branco tendo declarado numa entrevista que o governo João Goulart queria fazer uma universidade marxista com um biombo dominicano na frente [risadas do público].

RM - Por falar no marxismo, seu contato foi na USP ou os dominicanos já o apresentaram ao Marx?

OR - Já, num certo sentido, era uma referência filosófica. Quando eu estava na USP, 
nós constituímos um grupo de estudos só para estudar Marx e lermos O Capital. Um dia eu estava em Paris, o professor Ruy Fausto me apresentou, eu já com uma certa idade: "Está aqui um rapaz que aos vinte anos de idade leu O Capital inteiro". Mas isso não quer dizer que eu tinha entendido tudo [risadas do público]. Nem que eu tivesse aderido ao materialismo dialético, ao meu ver sem fundamento, não responde às suas condiçôes de possibilidades racionais.

RM - Aí está uma coisa bem interessante, que é essa ligação do marxismo com a religiáo cristá. No Museu do Ceará tem uma sala em homenagem a Frei Tito e lá tem um livro que ele utilizava, que trazia um diálogo entre Marx e Jesus Cristo. Como é que vocês pensavam essa relaçáo da filosofia marxista com a religiáo? O Sr. acabou de dizer que nunca concordou com o marxismo, o marxismo-leninismo ou com essa visão mais materialista. Como combinar isso?

OR - Não, o materialismo já tinha. Nem foi ele quem criou a expressão, foi Engels. O materialismo histórico, que estudava a evoluçáo dos processos sociais de produção, que é descrito no Capital. E que abriu um continente novo na história, táo novo que vocês devem conhecer a escola Des Annales, dos Anais, na França, com Braudel e outros. Isso mudou a maneira de fazer história, não é? Já não se procurava se o fulano e o beltrano eram realmente de sangue azul ou não, mas os grandes movimentos da história. Nesse sentido, eu li o Marx como Santo Tomás de Aquino leu Aristóteles. Ele não se tornou, deixou de ser cristáo porque leu e aprofundou o pensamento de Aristóteles. Eu também não mudei a minha fé, não fiz nenhum acréscimo, mas cresci intelectualmente entendendo o que Marx queria dizer. Eu entendi melhor o mundo em que eu vivia, eu não tinha ilusōes.

RM - Então, chamar a vocês, dominicanos da época, de comunistas era um equívoco?

OR - Totalmente. Aliás, eu nem sei se o Partido Comunista Brasileiro [PCB], eles que me desculpem, meus queridos amigos, até que ponto eles eram realmente marxistas. Primeiro, que não existia no Brasil $O$ Capital. Para ler $O$ Capital, primeiro você tinha que saber ou alemão ou francês, ou então ir até Buenos Aires para fazer a compra, não é? $\mathrm{E}$ assim mesmo tinha um resumo. $\mathrm{E}$ tinha todos esses comunistas que não tinham lido Marx. Por incrível que pareça, O Capital é traduzido no Brasil no tempo da ditadura. Só durante a época da ditadura eles foram aprender o que Marx dizia. O que não os torna, desculpe-me eu estou fazendo quase que uma brincadeira aqui, o que não os torna menos marxistas. [...].

RM - O Sr. não se tornou marxista, mas se aproximou, junto com vários outros dominicanos, dos marxistas, de militantes revolucionários e, sobretudo, da Ação 
Libertadora Nacional. Como foi isso?

OR - Essa aproximação, esse estudo mais sério de Marx, ele se deu no mesmo momento que estudantes, jovens como eu, que estavam na Açáo Católica, davam uma guinada muito séria para a esquerda e encontravam Marx. Eu os encontro, mas ao mesmo tempo eu sou amigo de pessoas como Vladmir Palmeira, um bando de gente que era dissidente, um pouco dissidentes, do Partido Comunista. O meu enfoque da realidade brasileira, a partir do conhecimento que eu tive d'O Capital, me levou a me aproximar muito mais das opçóes que eram dos comunistas. [...].

RM - E a Ação Libertadora Nacional atraía vocês. Por quê??

OR - Porque aí não se tratava de um partido, se tratava de uma frente. Uma frente que deveria reunir os patriotas, os democratas, os comunistas, os cristáos, era uma frente contra a ditadura. O objetivo é destruir a ditadura. É derrubar a ditadura. Depois, cada um fica na sua e vai lutar na sua. Era esse aspecto de frente e também a personalidade de Marighella. Ele, o antidogmatismo radical. Era como se a experiência toda do Partido o levasse a fazer, em tudo que ele projetava, exatamente o contrário do que era feito dentro do Partido. O que talvez tenha sido um erro. Porque ele descuidou muito do aspecto orgânico. "O dever do revolucionário é fazer a revolução, não é ficar em blábláblá". "Um revolucionário não tem que pedir licença a ninguém para fazer um ato revolucionário".

RM - Esse é o Marighella dizendo?

OR - Sim. Eu estou em Genebra um dia, abro o jornal e olho: "Embaixador norteamericano foi sequestrado no Brasil". Os frades ficaram felizes com aquilo. Eu fiquei abalado, porque eu conhecia a nossa situação, a correlação de forças existentes. Eu sabia que ALN eu tinha deixado, que grupos eu tinha deixado. Eu sabia que estava chuchando a onça com vara curta e que aquilo corria o risco de matar, no ovo, o movimento revolucionário no Brasil.

RM - Me parece que foi à revelia do próprio Marighella, não é?

OR - Foi. Logo depois, dois meses, chegou uma emissária dele lá em Paris que, então, me disse pessoalmente: "O Marighella ficou muito contrariado, mas como bom revolucionário, ele não desmentiu, não negou, não condenou o que tinha feito”.

$\mathbf{R M}$ - Até porque o pessoal estava fazendo o que ele dizia para fazer. 
OR - É, tem que ser coerente, não é? Mas vocês percebem que houve aí um descompasso? Você tinha que ter uma organização um pouco mais forte politicamente. Mais forte no sentido de ter diretrizes mais claras. Era preciso que todos tivessem consciência que aquele momento náo era o momento para fazer uma açáo desse tipo. Ora, chegou o pessoal do MR-8 [Movimento Revolucionário Oito de Outubro] - do qual fazia parte, aliás, meu grande amigo Franklin Martins - se juntaram, pediram apoio à ALN, que tinha meios para isso, para realizar o sequestro. Ora, ali há um salto de qualidade na repressão no Brasil. Já não eram aqueles bobôes - que me perseguiram, por exemplo, de carro nas ruas de Sáo Paulo e nós fugimos, eles sumiram também, nunca nos encontraram. Quer dizer, a gente zombava um pouco da nossa polícia, dizendo: “Como são burros!". É... Ali a coisa mudou de qualidade.

RM - Agora, a relação de vocês, dominicanos, com a ALN? Chegava a ser uma relação orgânica? Vocês chegaram a ter uma célula no convento?

OR - Houve outros frades que apoiaram essa perspectiva. Quando Betto e eu fomos conversar com o Marighella a primeira vez, ele nos convidou. Justamente por causa dessa ligação com essas pessoas da universidade. Foi através do mundo universitário que chegamos a ele. O Marighella quis um encontro e nós fomos, e fomos com o pé atrás. E, para nós, estávamos indo falar com o dirigente do Partidáo, com cuja linha nós não concordávamos, que era de ser tolerante demais com a ditadura. Eles pregavam a paciência, calma, não é? "Vamos conscientizar o povo, vamos reorganizar".

RM - Se encontram antes do rompimento público do Marighella com o Partido?

OR - Antes.

RM - Então, deve ser início de 1967, talvez?

OR - Exato, antes da ida dele para Cuba. Eu assisti, como convidado, à reuniáo do comitê dos intelectuais comunistas de São Paulo. Era uma reunião orgânica do Partido, onde foi lido o comunicado da expulsão de Marighella, porque ele tinha tomado partido em favor da luta armada. Eu me lembro que, nessa ocasião, vários protestaram: "Sem consultar ninguém?”. Como se algum dia o Partido tivesse consultado alguém para expulsá-lo. E houve protestos. O meu amigo [Jacob] Gorender, que tinha uma visão diferente, queria criar um novo partido revolucionário. Também se levantou contra a expulsão. $\mathrm{O}$ voto foi quase unânime contra a decisão. Eu só tomei a palavra uma vez, foi quando meu amigo Jacob Gorender - historiador, publicou um livro - disse que era preciso fazer um novo partido, um partido revolucionário, que tinha que ter uma coisa orgânica, não se poderia fugir do modelo leninista, comitê organizado, etc. Aí eu tomei 
a palavra e falei: "O companheiro que me perdoe, mas se Fidel Castro tivesse esperado a constituiçáo de um comitê de intelectuais em Cuba, ele jamais teria feito a revoluçáo”. Eu fiquei muito sem graça, porque houve uma gargalhada geral. Mas, felizmente, eu não perdi o amigo. Retomando a conversa com Marighella: ele era favorável à luta armada, mas que a luta devia ser travada por todos. Não tinha modelo, o Brasil não entrava nos modelos existentes de luta armada. O golpe era militar e a resistência do povo brasileiro teria que ser como a do Vietná, como a dos povos que foram esmagados pelo imperialismo, etc. E com efeito havia isto, havia um povinho pequeno que lutava, valentemente, contra, talvez, a maior potência que já existiu na face da terra, armada suficiente para destruir mais de cem vezes o planeta. Aquele paisinho lá, quase que com bodoque, mas não tinha armas. $\mathrm{O}$ Marighella veio até nós e pediu apoio. Claro, seria preciso frentes guerrilheiras. Primeiro, uma frente guerrilheira que, ele pensava, tinha que vir da área rural, o Brasil era ainda um país rural. E tinha um elemento importante, que eu só fui descobrir depois: o Marighella foi o único membro do Partido Comunista Brasileiro que náo fez aqueles estudos fundamentais para ser dirigente em Moscou, mas na China. $\mathrm{Na}$ China não foi como na Rússia, não foi um palácio que eles tomaram, foi uma marcha que eles fizeram. A marcha, que foi aumentando, aumentando, o campesinato se juntando ao proletariado até tomar Pequim.

RM - No entanto, a ALN acabou não tendo nenhuma ação rural relevante, não é? Mas teve planos?

OR - Não, e aí é que está. Ele concebia a ação urbana como uma ação tática, de preparação, porque precisa de meios. É preciso meios para se instalar no fundo do Brasil e depois espalhar grupos armados, que seria, segundo ele, necessariamente um processo muito longo. Não íamos sair dando tiros e vencer o Exército brasileiro. Teria mesmo que haver dissensão e divisão dentro do Exército brasileiro, ter que ganhar o povo brasileiro. A ação inicial seria uma ação tática, que era buscar os meios financeiros para promover a revoluçáo. Daí porque, de repente, eu lembro uma vez, eu estava na rua, comprei um jornal, li e disse assim: "Um banco foi assaltado, curiosamente um dos ladrôes tinha uma metralhadora". Eu falei: "É a ALN". Eles eram organizados de uma maneira que só bobo não ia descobrir que não se tratava do mesmo bandido. Mas a polícia brasileira não desconfiou de nada.

$\mathbf{R M}$ - E o senhor colaborou com a ALN em que medida?

OR - A colaboração que ele precisava era de uma retaguarda. Uma retaguarda logística. Nós estávamos dispostos a ajudá-los, estando muito claro que nós, a nossa situação e as nossas convicções, nós não iríamos pegar em armas. Não faria muito sentido, ainda que na França houvesse dominicanos franceses que fizeram parte da resistência francesa 
contra o nazismo e, na frente do convento, tem uma placa enorme com o nome de todos os frades dominicanos que morreram de fuzil na mão contra os nazistas. E nós eles também, sobretudo - temos isso como uma grande honra, estarmos inscritos entre aqueles que deram sua vida contra o nazismo, o que não aconteceu em nenhuma outra ordem religiosa. Mas nós não estávamos no momento de pegar em armas. E também [havia] o nosso poder de convencimento com os contatos que nós tínhamos nos meios culturais, acadêmicos, etc. Era um apoio logístico e era também, aos olhos dele, um apoio moral, importante.

RM - O Sr. acabou sendo enviado pela ordem para a Europa em 1969. Então saiu do Brasil antes que houvesse o processo de desmantelamento da ALN? Isso tem alguma razão política? Quiseram afastá-lo?

OR - Eu era uma pessoa muito evidente. No congresso da UNE [União Nacional dos Estudantes], em Ibiúna, eu sou um dos organizadores. O prior do convento dos dominicanos, Frei Chico, é preso. Entram dentro do convento e o levam. O que nós fazemos? De hábito, fomos para frente do DOPS [Departamento de Ordem Política e Social]. Não podiam imaginar, eles olhavam pela janela e falavam assim: "Ué, estão doidos". Imagina um grupo enorme de frades na frente do DOPS. Aí desceram: "Mas o que é isso? O que os senhores estáo fazendo aqui?". Aí falamos: "Prenderam o prior do convento, nós viemos buscá-lo". Houve um momento de hesitação, eles não sabiam o que fazer, até que desceram três ou quatro, aí, eu năo sei porquê - seguramente não foi a divina providência [risos do público] - vieram logo para mim e o frei Mariano, coitado, e fomos levados para dentro do DOPS, presos. De fato, nós fomos levados para tomar um cafézinho pelo delegado Bonchristiano, que comandaria as operaçóes para pegar em Ibiúna, que depois nos levou ao gabinete, ao diretor do DOPS. Consternado, triste, nos dizendo o seguinte: "Mas vocês deveriam ser os nossos maiores aliados, nós estamos combatendo o comunismo e vocês agora vêm aqui combater a gente?". "Não é isso que nos trouxe aqui, entraram no convento e prenderam o prior, o superior da casa, nós viemos... Cadê ele?". "Eu estou dizendo pro Sr., não fomos nós, nós não prendemos". "O senhor está dizendo, mas o Sr. acha que nós vamos acreditar? O senhor vai ter que prender todo mundo aí, porque ninguém vai acreditar”. Ele pegou e nos levou para visitar todo o DOPS. E, ao passar, eu vi, inclusive, um colega padre prestando depoimento, porque tinha acabado de haver um congresso da união estadual, em Campinas, numa casa de religiosos. Nós o cumprimentamos. Quando voltamos para o escritório, para o gabinete do diretor, ele falou: "Os senhores viram, não está aqui, estão contentes?”. Aí o frei Mariano: "Não senhor, porque o que acabamos de ver aí é que está cheio de gente presa, náo podemos ser solidários só com o prior, somos solidários com aqueles que estão presos. O padre está lá, está preso porquê?". Aí o delegado olha para o frei Mariano: "Eu conheço o senhor". Ele era um pouco mais 
velho do que eu: "O senhor não é de Campinas?". "Sou”. "Mas não é possível, eu conheci o senhor fazendo uma manifestação na frente de um cinema, contra um filme pornográfico" [risos do público]. De pornográfico não tinha nada. $\mathrm{O}$ frei Mariano, com efeito, pertencia à congregaçáo Mariana antes de entrar para a ordem e, entrando para a ordem, ele mudou [risos do público]. $\mathrm{O}$ delegado não entendia. E aí ele virou-se para nós: "O senhor sabe que eu posso processá-los pela Lei de Segurança Nacional?". Aí fui eu que falei: "Pode. Mas eu li no jornal que até o presidente da República estava envergonhado com isso, porque disse que preferia nunca aplicar essa Lei de Segurança Nacional, de forma que, para nós, isso é inaceitável”. Aí ele achou que nós estávamos falando demais, que já estava na hora de ele se proteger e mandou chamar a imprensa: "Para ver, como esses comunistas são". Aí a imprensa entrou e nós acabamos com a ditadura. De repente, chega alguém e o chama, o delegado do DOPS, ao telefone, ele sai e volta: "Bom, podem ir embora, os senhores estão soltos. Espero que não nos vejamos mais". Aí eu falei: "Bem, esperamos" [risos do público]. E fotografados pela imprensa. Burro - desculpem a expressão meio vulgar, mas foi a impressão que nos deu - nos liberando e tendo chamado a imprensa. No dia seguinte, tem uma página do jornal Última Hora, onde tem uma fotografia minha, desse tamanho [faz gesto com as máos], saindo do DOPS. Vocês podem imaginar por aí, eu creio, que não é preciso muita argúcia para isso, o ódio com que eles se abateram sobre nós no dia que nos prenderam. Nós estávamos lá, na frente deles.

RM - Mas o senhor chegou a ser preso depois?

OR - Não.

RM - O Sr. já estava na Europa?

OR - Aí eu fui... Acontece que a ordem tem um plano de estudos para os frades. Às vezes, os superiores têm ilusões, como os professores têm ilusões sobre seus alunos. Tiveram um pouco de ilusão sobre minhas qualidades intelectuais e já tinha sido decidido que eu ia perfazer a minha formação na Europa. E eu fui adiando. Isso foi decidido logo no fim de 1966, passou 1967, passou 1968, até que o provincial me chamou e disse: "Olha, já foi decidido faz dois anos, que o Sr. deve ir. Então faça sua mala e vá. Porque, inclusive, você é muito solicitado, é visível o seu comprometimento político na universidade, você vai ser preso a qualquer momento, entáo, vai embora, some daqui. O Frei Betto também. Ele vai para o Rio Grande do Sul”. Eu fui para Europa. É uma injustiça, não é?

RM - O senhor deu mais sorte, talvez, não é? Eu digo, não o alcançaram na Europa, não é isso? $\mathrm{O}$ Frei Betto acabou sendo alcançado. 
OR - É, eu acabei de dizer uma grande bobagem, eu reconheço. Eu não sei quem é que teve sorte aí, o fato é que ele foi para São Leopoldo, lá com os jesuítas, e eu fui enviado para a Suíça, onde estava frei Carlos Josaphat, aquele que justamente tinha me atraído para a ordem dominicana. Fui para estudos, e muito chateado, porque eu não queria ir. Marighella, inclusive, falou comigo: "Não tem o menor impedimento. Você está achando que a luta vai durar pouco? Aqui vai ser quase uma década. Nós nem começamos nada ainda. Você pode ir, fazer seus estudos, diplomar... Fazer o que você quiser, vai voltar e ter o que fazer ainda. E além disso tem o serviço que você pode prestar. Lá no exterior, pode ser o nosso porta-voz, explicar o que está acontecendo no Brasil. Organizar melhor". Bom, foi assim... Daí porque eu fui embora e sai livremente com o meu passaporte. Passei pela polícia. Sem prever um desenlace táo rápido e táo trágico.

RM - O Sr. estava na Europa quando aconteceu a morte do Marighella, a prisão dos seus colegas dominicanos. Como foi o impacto dessa notícia para vocês lá na Europa?

OR - O impacto foi profundo. Eu estava em Roma, justamente, fui me despedir de uma pessoa que ia para Cuba e depois eu fui almoçar num restaurante com dois cineastas italianos que estavam nos apoiando muito. Quando terminou, eu disse: "Tenho que voltar para a Suíça e vocês poderiam ver para mim, eu estou com a passagem, precisa marcar só a hora". "Ah, vou telefonar para minha mulher". Um deles telefonou e quando voltou ele estava lívido e me disse: "Vamos lá para casa, que minha mulher tem uma notícia importante para te dar”. Imagine, eu estava no Largo Argentina, em Roma. Fomos, ele morava perto. Quando nós chegamos ela estava ao telefone e ela me disse: "Acabei de receber a notícia de que mataram Carlos Marighella". "Mas como assim, em que circunstância mataram?”. Ela telefonou para os jornais de novo e deram a seguinte notícia: "Marighella foi morto junto com Carlos Lamarca". Falei: "Não, isto é impossível. Ou mataram um, ou mataram outro. Porque o Marighella jamais se encontraria com o Lamarca. Telefona para saber melhor". E ela resolveu telefonar para Agence France-Presse, e, séria, foi dizendo coisas ao telefone. A primeira palavra foi "Na Alameda Casa Branca", aí eu já reconheci, e "dominicanos". Essas duas palavras pronunciadas tornaram evidentes para mim que Marighella tinha sido assassinado, porque era na Alameda Casa Branca, em Sáo Paulo, que eu me reunia às vezes com eles. E é evidente que se ele se encontrou com um dominicano, só podia ser lá. Então, eu fui imediatamente para a casa de um amigo. Telefonei para o frei Carlos: "Olha, aconteceu uma coisa, fico por aqui. Vou ver o que aconteceu". Na casa de um amigo, recebo o telefonema do Toledo Câmara Ferreira, que era o segundo homem depois do Marighella, estava de passagem em Paris e iria para a Coreia. Era ele que tinha organizado o sequestro do embaixador norte-americano. O Marighella disse para ele: 
"É melhor você tomar distância". Mas não o enviou para Cuba, disse para ele ir para a Coreia. E agora estava ali, um pouco perdido com uma situação dessas, e ele queria ir para Cuba. E, para ir para Cuba, ele só iria a partir do momento que eu o apresentasse e lhe desse direito de passagem. Foi assim que eu o recebi. Mas eu conversei com o Toledo, fiz o necessário, depois nós embarcamos juntos para Cuba, onde estavam os brasileiros. Eu, por uma questáo de honra, eu náo sabia bem o que tinha acontecido, mas os dominicanos estavam misturados. Eu fazia questão de dizer: "Nós não abandonamos, eu estou chegando aqui junto com o Toledo". E, curiosamente, viajamos em aviốes diferentes, para não sermos percebidos. Nós fomos muito bem recebidos, com todo respeito, pelos companheiros que estavam lá em Cuba.

RM - Então, o Sr. acompanhou o Toledo nessa viagem a Cuba? A partir de Cuba, o Toledo voltou ao Brasil?

OR - Voltou. Eu queria voltar também, mas ele disse: "Olha, uma loucura, só o que a gente vai ter que gastar com pessoal e recursos para garantir a sua segurança, vai ser uma coisa absurda, quando você pode ser muito mais útil na Europa. Na Europa, você pode servir de intermediário. Se for necessário, vir a Cuba”. Então, foi assim que as coisas se passaram, porque esse sentimento de ver os seus companheiros acusados de traiçáo é um sentimento muito duro. Saber que foram torturados daquela maneira é uma coisa muito dura, muito chocante. Eu não vou chegar ao ponto de dizer que foi mais duro do que ser torturado. Mas era uma coisa muito pesada de ser carregada. A gente se sente como que um pouco responsável, não é? Afinal, fui eu que falei com o Marighella primeiro, junto com o Betto. E, eu não sei se vocês lembram, tem uma peça de [Georges] Bernanos, chama-se O Diálogo das Carmelitas. A superiora faz todas as freiras fazerem um voto - era durante a Revolução Francesa - de recusar a declaração da Revolução sobre a religião que o Papa tinha recusado, dizer "não". E a superiora sai do convento para fazer algo, quando ela volta, encontra o convento invadido e as freiras já sendo levadas para a guilhotina. E ela quer ir e o padre, que está ali celebrando uma missa, inclusive, pelas irmãs, fala assim: "Não, você não pode ir". "Mas eu levei elas para a morte". "Você não pode ir, porque o combate tem que continuar. A ordem também tem que continuar, então não vá”. Quer dizer, com um pouco de exagero, eu não era superior de ninguém, mas era esse sentimento de ter sido deixado de lado. E, de uma certa maneira, um sentimento profundo de impotência. Você fica totalmente sem saber o que fazer.

Marina Camisasca $^{2}-[\ldots]$ O que você, lá no exterior, fez efetivamente para tentar

Marina Camisasca é pesquisadora do NHO/LHTP e doutoranda em História pela UFMG. Sua pergunta demarcou o início do momento de interação do entrevistado com o público presente na entrevista 
ajudar os freis que foram presos na Operação Batina Branca?

OR - Ah, muita coisa foi feita. Desde a morte do Marighella, nós fizemos um comitê e foi a primeira grande reuniáo pública depois de maio de 68 . Foi em protesto contra o assassinato de Marighella e nós conseguimos levar, para presidir, nada mais nada menos que o filósofo Jean Paul Sartre. Isso teve uma repercussão imensa. E vou contar uma outra, que parece até piada. Há todo um processo organizativo, mas seria falar demais. Estou lá em Roma, um dia, quando chega do Brasil a Sônia Lins, grande militante, que não pertencia à ALN, pertencia a um outro movimento, e ela me traz e me apresenta uma cruz pequena. Eu vejo a cruz, está assinada "Betto, Ivo, Fernando e Tito". "Sim, é para mim que eles enviaram isso?". "Não! Eles querem que você entregue isso ao Papa”. Não faltava mais nada: "Eu, um humilde frade, entregar isso ao Papa, vocês ficaram loucos?" [risos do público] Mas nós tínhamos relaçôes de amizade e ela se comprometeu com a nossa causa. Era uma pessoa importante, inclusive porque ela fora da Ação Católica movimento que tinha tido como seu assistente principal o entáo padre Montini, que, naquela altura dos acontecimentos, estava no comando da Igreja, era o Papa Paulo VI. O marido dela se tornou o presidente da IRI [Istituto per la Ricostruzione Industriale], [que] foi criado logo depois da guerra e agrupa todas as empresas nacionalizadas da Itália. Isso quer dizer que era como se colocasse a Vale, a Petrobras, tudo numa mesma companhia, com um só dirigente. Você pode imaginar que, portanto, não era qualquer um. Eu falei "Vou recorrer a ela". Fui, ela tinha uma livraria, mostrei e falei: "Olha, essa é a cruz dos frades, mandaram para o papa de presente e estão pedindo para chegar até ele." E ela vira assim para mim: "Mas é muita coincidência! Amanhã é aniversário do papa”. "Mas como fazer? Eu não posso chegar lá e falar: 'Os frades da prisão lhe enviaram isso', sem prova, sem nada...". "Mas quem foi que disse?". "O frei Oswaldo" [risos do público]. Aí eu tive que usar um estratagema. Eu reconhecia a assinatura do Betto e do Ivo. O Ivo, certinho, parecia um desenho, a assinatura. A do Betto, toda torta. Muito fácil reconhecer a assinatura de meus amigos, meus colegas. Mas precisava de uma autoridade. Soube que o Mestre da Ordem, nosso superior geral, estava em visita canônica, de inspeção, portanto, na Universidade do Angelicum, em Roma. E ele estava com seu assistente, que nos dava o apoio, que seguia o assunto do Brasil, chamava-se frei Vicente de Couelombe, que depois se tornou Mestre da Ordem. Aí eu falei: "Me arranja um carro, que eu vou lá". Fui lá: "Oh, frei, você aqui, como é que vai? O que você está fazendo?". Conversamos alguma coisinha, aí eu mostrei: "Olha, recebi isso. O senhor conhece a assinatura, não conhece? Aqui é do Betto, do Ivo”. "Ah, sim... Eu tenho cartas que eles escreveram da prisão. Sim, eu reconheço, mas o que você quer com isso?". "Eles mandaram de presente para o papa”. Aí ele soltou uma gargalhada: "Muito bem, e você vai entregar para o Papa, eu estou procurando". "O senhor conhece a autenticidade?". "Sim, isso é evidente. Mas Oswaldo, desiste, que isso é impossível”. "Muito obrigado!". Corri. Mostrei para Marcela Glisenti, o 
nome dela. Marcela telefona diretamente para o Cardeal Secretário de Estado, cardeal [Jean-Marie] Villot - ele também não suportava os militares brasileiros - e fala do que se trata. "O Cardeal Secretário de Estado, tem entrevista com o papa às 8:30 todo dia. Eu posso entregá-lo, mas você tem que vir aqui antes. Tem que chegar antes das $8 \mathrm{~h}$, antes das 8:30, tem que me entregar a cruz e eu entrego para ele". No dia seguinte, bem cedinho, eu fui para casa dela. Eu vejo o senhor Giuseppe Glisenti, o homem economicamente mais poderoso da Itália, de rob de chambre, um camisoláo e uma máquina fotográfica, tirando fotografia da cruz. Ela, se arrumando. E aí nós saímos - ela, correndo - para o Vaticano. Ela parou o carro, correu para o fotógrafo para revelar as fotos. Eu fui correndo, "precisamos dessa foto urgente", revelaram as fotos. A secretária da sua livraria, livraria Paese Nuovo, tinha chamado a imprensa inteira. Nós chegamos, distribuímos as fotos, dizendo que o Papa tinha recebido esta cruz dos frades presos no Brasil. Uma boa parte dos jornais italianos saía à tarde, na Europa também. Por exemplo, o Le Monde sai à tarde. E foi assim que, mais ou menos lá pelas $14 \mathrm{~h}$, o embaixador do Brasil, o governo italiano e o governo brasileiro souberam, com título garrafal, a fotografia da cruz, na primeira página dos jornais. Fazer o quê, não é? O papa tinha recebido a cruz e ali era uma denúncia muito forte.

RM - Essa questão do Vaticano é muito importante porque alguns anos depois, salvo engano, o mesmo papa, em 1970, fez uma declaração se referindo a um grande país católico em que havia muita violência e isso teve um impacto importante no Brasil também.

OR - Foi o Paulo VI. É só ver o movimento dentro da Igreja. O cardeal Agnelo Rossi, de São Paulo, era pró-ditadura. Quando visitou os freis presos, falou: "Mas vocês não estavam celebrando missa quando vocês foram presos". Ele foi convidado a vir para Roma, assumir uma função, deixando vago o cargo. Nós tínhamos um bispo auxiliar em São Paulo que era dominicano. Dom Lucas [Moreira Neves]. Só que, quando Frei Tito foi torturado pela segunda vez, barbaramente, o Mestre da Ordem - não é qualquer um - pediu a ele: "Você podia fazer pelo menos uma declaração, dizendo que você viu o Frei Tito nesse estado aî". O Dom Lucas responde: "Olha, isso não adiantaria nada. E, além disso, isso prejudicaria a minha atividade pastoral na cidade". O Mestre da Ordem vai falar com o cardeal e fala: "Eu gostaria que o Sr. designasse um bispo para acompanhar os frades que estáo presos na cadeia”. E Dom Lucas, ao Mestre da Ordem, diz: "Eu não quero". O cardeal sabe quem é o Mestre da Ordem dos dominicanos, ele sabe o que significa essa gente, assim como o superior geral dos jesuítas também. A gente não brinca com essa gente. E ele aí fala assim: "Vou pedir para o Dom Paulo". Ele chamou o Dom Paulo Arns e falou: "Olha, você tem que ir lá cuidar dos dominicanos, visitar". E o Dom Paulo disse: "Olha, eu estou sem graça, porque tem o meu colega que é dominicano, por que eu, que sou franciscano, é que 
vou lá? Ele vai ficar chateado". Aí o cardeal disse a Dom Paulo: "Olha, eles é que preferem que seja você". "Ah, então eu vou”. E é assim que Dom Paulo Arns entra na prisão, para visitar os dominicanos presos, e é lá que ele fala com os prisioneiros, e é lá que ele descobre a realidade da ditadura. Como é um homem honesto, profundamente honesto, ele sai de lá com uma disposição: acabar com a ditadura. Imediatamente, ele é nomeado cardeal em São Paulo e os seus assessores são homens notáveis. O Angélico, de quem eu falei, padre que eu admirava e um bispo que certamente vai ser canonizado; Dom Luciano... eram homens dessa têmpera. O episcopado brasileiro mudou todo, por toda parte, você tinha o [Dom Frei Aloísio Leo Arlindo] Lorscheider nomeado aqui, bispos valentes que chegaram a excomungar polícia, que lançaram comunicados. Começa aí a resistência da Igreja contra a ditadura, que náo vai ser a mesma resistência que a de Carlos Marighella, mas que não deixará... não foi, seguramente, menos eficaz. Tudo isso está traçado em livros, que podem ser vistos por aí. De certa maneira, eu posso dizer que uma das causas do Ato Institucional $n^{\circ} 5$ - nós perdemos, às vezes, a perspectiva das coisas, achando que, dizem: "eles fizeram o Ato Institucional $\mathrm{n}^{\circ} 5 \mathrm{em}$ resposta à luta armada." Não havia luta armada organizada. Havia aquelas tentativas em São Paulo. De vez em quando tinha um grupo que jogava uma bomba ali, você nem sabia direito se eram realmente gente de esquerda ou gente de direita. O fato é que, eu me lembro de uma cena perfeita: os estudantes, houve o Congresso de Ibiúna que caiu, não porque foi mal organizado, é que houve uma burrice. Disseram, eu vi na internet, que, contra [o voto da] a Ação Popular, foi feito clandestinamente. Não foi verdade: a Ação Popular é que insistiu para que fosse feito clandestinamente, fora da cidade. $\mathrm{O}$ grupo do Zé Dirceu e do Vladmir queria que fosse no Tuca [Teatro da Universidade Católica de São Paulo], no teatro: fazia-se a eleiçẫo, aí a polícia ia chegar, ia prender todo mundo, seria um escândalo. Bom, aconteceu a mesma coisa, só que ninguém foi eleito, não teve tempo. O fato é que o Congresso de Ibiúna caiu, novecentos presos. A universidade brasileira tinha um milháo e seiscentos mil estudantes, em 1968. Hoje ela tem oito milhôes e meio mais ou menos. Não é difícil, não precisa ser muito inteligente para perceber que esses estudantes universitários não são filhos das classes laboriosas do Brasil. São os filhos da nossa boa classe média. Novecentos deles são levados presos. Eu poderia até contar outras histórias, como o movimento das mães que se organizaram. Eu escapei por um triz. A classe média ressentiu. "Meu filho?". Eu fico imaginando a mãe telefonando para o pai, empresário: "Prenderam o Luisinho". "Quem?". "A polícia”. "Quem?”. "O DOPS. A polícia política" [risos do público]. Comoção, não é? Eu me lembro... Soltaram todo mundo. Só sobrou seis presos: o Zé Dirceu, o Vladmir, o Travassos, o Ribas e o Franklin Martins, eu confesso, eles me desculpem, não sei porquê. E eu me lembro de uma noite em que a mulher do Vladmir Palmeira estava de passagem em São Paulo e nós fomos à casa de uma irmã do Franklin Martins, onde ia chegar o senador Mário Martins, pai do Franklin, trazendo-nos notícias de como tinha sido a sessão do Supremo Tribunal Federal [STF]. Daí a pouco chega o senador, feliz: "Deram o habeas corpus ao meu filho Franklin Martins, o Supremo concedeu." 
Inevitavelmente, diz Mário Martins, e com toda razão: "O supremo terá que dar a todos os outros". Pela força da conformidade com as formas.

$\mathbf{R M}$ - Efeito vinculante.

OR - Exato. E, você veja: o Congresso Nacional acabara de recusar a cassação do mandato do deputado Márcio Moreira Alves, que tinha ofendido o Exército. Os militares pediram a sua cassação, os deputados recusaram. Não foi cassado. O Supremo concedeu habeas corpus a esses "criminosos", váo estar todos na rua daqui a pouco. A Igreja protege manifestaçáo de estudantes, os padres se dando a mão para fazer uma corrente nos dois lados, os estudantes no meio, e a tropa ali com a arma na máo. $\mathrm{O}$ que os militares perceberam aí - e outra: e o empresariado nervoso. Sem contar que a imprensa mesma já começava a dar sinais sérios de aborrecimentos. A ditadura estava politicamente vencida. E havia já alguém para suceder, um grupo para suceder, que era o grupo que tinha sido formado, apesar de ter sido destruído -, destruído quer dizer "colocado fora da lei", mas ele existia, entre homens como o João Goulart, Juscelino Kubitschek e Carlos Lacerda, o principal inimigo de todos eles. Quer dizer, a oposição estava organizada politicamente e não era brincadeira, eram três nomes extremamente fortes da política brasileira, entre os quais dois ex-presidentes da República. Eles perderam a classe mais importante e perderam a sociedade civil. E foi aí que o chefe do SNI [Serviço Nacional de Informaçôes], general Figueiredo, comunicou ao comando: "A situação está perdida, nós temos que ir para a força mesmo". No dia 13 de dezembro, dava para pressentir que ia acontecer alguma coisa, uma vez que o Estado de São Paulo publicou um editorial: "As instituiçōes em frangalhos". O jornal foi destruído, entraram no jornal, destruíram toda a edição, invadiram o jornal $O$ Estado de São Paulo. Vocês não podem imaginar o que isso significava naquele contexto. $\mathrm{O}$ jornal que mais apoiou o golpe de Estado e os militares denunciava os militares. E, à noite, foi declarado o Ato Institucional $\mathrm{n}^{\circ} 5$, cujas consequências o professor já mencionou, não é? Quer dizer todos os direitos e garantias individuais suspendidos, o parlamento em recesso, acaba-se com o habeas corpus, aumenta-se o aparelho repressivo, a máscara, a fantasia foi rasgada. A fantasia para quem gosta de fantasia, porque era evidente que era um regime ditatorial, um dos mais violentos que já existiu, e que ali mostrava sua face totalmente. Perder a Igreja, é bom que saibam, é politicamente perigoso.

\section{Referências}

BETTO, Frei. Batismo de sangue: os dominicanos e a morte de Carlos Marighella. 4. ed. Rio de Janeiro: Civilização Brasileira, 1982. 
SANTHIAGO, Ricardo. "Ela foi meu muro": liberdade artística e liberdade narrativa em uma metaentrevista pública. Revista Memória em Rede, v. 10, n. 18, p. 83-111, 2018.

Recebido em 26/03/2021.

Aprovado em 19/04/2021.

Contribuiçóes dos autores: Hermeto: concepção e planejamento da pesquisa, trabalhos técnicos de gravação, redação do texto de apresentação, edição da entrevista; Amato: concepção e planejamento da pesquisa, trabalhos técnicos de gravação, redação do texto de apresentaçáo, edição da entrevista; Santos: concepçáo e planejamento da pesquisa; trabalhos técnicos de gravação; redação do texto de apresentação; edição da entrevista.

Fonte de financiamento: nada a declarar.

Conflitos de interesse: nada a declarar. 